Creative Commons User License: CC BY-NC-ND

Abstracted by: EBSCOhost, Electronic Journals Service (EJS),

Google Scholar, Journal Seek, Scientific Commons,

Food and Agricultural Organization (FAO), CABI and Scopus

http://eoi.citefactor.org/10.11226/v26i1
Journal of Agricultural Extension

Vol. 26 (1) January, 2022

ISSN(e): 24086851; ISSN(Print); $1119944 X$

http://journal.aesonnigeria.org

http://www.ajol.info/index.php/jae

Email: editorinchief@aesonnigeria.org

\title{
Factors Influencing Inorganic Fertilizer Use Among Rice Farmers in Ebonyi State, Nigeria \\ https://dx.doi.org/10.4314/jae.v26i1.4
}

\section{Iwuchukwu, Juliana Chinasa}

Department of Agricultural Extension, University of Nigeria, Nsukka Enugu State, Ngeria juliana.iwuchukwu@unn.edu.ng; +2348063276459

\section{Obazi, Sunday Alagba}

Department of Agricultural Extension, University of Nigeria, Nsukka Enugu State, Ngeria Corresponding author: sunday.obazi@unn.edu.ng; obazisunday@gmail.com; $+23408067839018$

\section{Opata, Patience Ifeyinwa}

Department of Agricultural Extension, University of Nigeria, Nsukka Enugu State, Ngeria patience.opata@unn.edu.ng; +2347066070155

\section{Madukwe, Michael Chukwuneke}

Department of Agricultural Extension, University of Nigeria, Nsukka Enugu State, Ngeria michael.madukwe@unn.edu.ng; +2348037006968

\section{Abstract}

This study examined factors influencing inorganic fertilizer use among rice farmers in Ebonyi state, Nigeria. A total of 120 rice farmers were purposively selected and used for the study. Data were collected by use of interview schedule and analyses were conducted using frequency, percentage, mean score and regression. Results showed that the respondents applied mostly urea fertilizer (54.2\%) usually once (55.8\%) on rice farm using broadcast method (100\%). The amount of fertilizer applied per hectare in rice farm was $85.63 \mathrm{~kg}$. Rice farmers' inorganic fertilizer use were influenced by number of years spent in school, years of experience in rice production, total size of farm used for rice, total annual income earned from rice production and number of extension agent visit. Surprisingly, rice output ( $t=1.243$; $p \geq 0.05)$ had no significant influence with inorganic fertilizer use. Government through the ministry of agriculture should organize workshops and train farmers on inorganic fertilizer use so as to enhance adequate use. Also, government and other relevant stakeholders in agriculture should ensure that inorganic fertilizers are available, accessible and affordable to farmers at all time so that they could maximally utilize it in rice production.

Keywords: Inorganic fertilizer; rice production factor. 
Creative Commons User License: CC BY-NC-ND

Abstracted by: EBSCOhost, Electronic Journals Service (EJS),

Google Scholar, Journal Seek, Scientific Commons,

Food and Agricultural Organization (FAO), CABI and Scopus

http://eoi.citefactor.org/10.11226/v26i1
Journal of Agricultural Extension

Vol. 26 (1) January, 2022

ISSN(e): 24086851; ISSN(Print); $1119944 X$

http://journal.aesonnigeria.org

http://www.ajol.info/index.php/jae

Email: editorinchief@aesonnigeria.org

\section{Introduction}

Rice is an annual crop and a staple food for teeming population worldwide (Onya, Okezie \& Ejiba, 2019). Principally, large quantity of milled rice is produced yearly, with China and India accounting for almost half of the total production and consumption (Bhandari, 2019). The crop is critical for food security providing considerable dietary calories for poor people in Asia and other countries of the world (Jat, Kakraliya, Choudhary, Kapoor, Kakraliya, \& Ram, 2020). Beside Asia and China, other countries such as Caribbean and Latin America also report a continuous increase in rice consumption among her people (Udemezue, 2018). In African region, rice is a rapid flourishing staple diet for both rural and urban populations. Nigeria produces highest in Africa (Udemezue, 2018) and used it in different way to meet several purposes.

As diets, rice provides sufficient amount of starch, protein, amino acids, vitamins and considerable amount of other minerals (Yang et al., 2017; Chaudhari, Tamrakar, Laxmi, Ambika \& Deepark, 2018; Saleh, Wang, Wang, Yang \& Xiao, 2019). In addition, Chaudhari et al (2018) noted that rice bran oil is used for cooking, soap making and fatty acid, cosmetics, detergents and synthetic fibres while its straw serves as a source of fuel, feed for animals, mushroom bed, mulching and for making compost and paper. Rice also serves as a cash crop and employs over 15 million people in its value chain (Onya et al., 2019).

Despite these invaluable importance, rice production in Nigeria is still plagued by myriads of setbacks ranging from difficulty in land acquisition, paucity of agricultural information and communication, inadequate training, issues of inappropriate technology, environmental constraints, pests and diseases, inadequate manpower, storage problems to inadequate and irregular supply of improved seeds, inadequate supply of inorganic fertilizers and other production inputs (Mohammed, Ibrahim, Hayatu \& Mohammed, 2019). Inorganic fertilizer is one of the most essential farm inputs for increasing food production in the universe (Jaja \& Barber, 2017). It is perhaps the quickest practical way to provide sufficient plant nutrients to restore nutrient-depleted African soils (Raimi, Adeleke \& Roopnarain, 2017). Aside replenishing plant nutrients in soil and promoting healthy growth of plants, it also increases crop yield and productivity if adequately supplied and efficiently used. Conversely, the insufficient supply of the product as well as other hindrances behind the efficient use may lead to undesirable outcome. Hence the need to ascertain factors influencing inorganic fertilizer use among rice farmers in Ebonyi state Nigeria. Specifically, the study described activities of rice farmers in the use of inorganic fertilizer and determined factors influencing inorganic fertilizer use in rice production in the study area.

\section{Methodology}

The study was carried out in Ebonyi State, Nigeria. The state is located between latitudes $5^{\circ} 4^{\prime} \mathrm{N}$ and $6^{\circ} 45^{\prime} \mathrm{N}$ and longitudes $7^{\circ} 30^{\prime} \mathrm{E}$ and $8^{\circ} 30^{\prime} \mathrm{E}$. Ebonyi State occupies a total 
Creative Commons User License: CC BY-NC-ND

Abstracted by: EBSCOhost, Electronic Journals Service (EJS), Google Scholar, Journal Seek, Scientific Commons, Food and Agricultural Organization (FAO), CABI and Scopus

http://eoi.citefactor.org/10.11226/v26i1
Journal of Agricultural Extension

Vol. 26 (1) January, 2022

ISSN(e): 24086851; ISSN(Print); 1119944X

http://journal.aesonnigeria.org

http://www.ajol.info/index.php/jae

Email: editorinchief@aesonnigeria.org

land area of 5,935 square kilometers and has a population of 2,176,947 people (National Population Commission (NPC), 2006). The state has good soil types (lowland and upland) and favourable climate for production of rice and other crops. All rice farmers in the State comprised the population for the study. Multistage procedure and purposive sampling technique was used to select the rice farmers. Four (Ikwo, Ezza north, Izzi and Ohaukwu) Local Government Areas (LGAs) were purposively selected based on their involvement in rice production. In each selected LGAs, three town communities were purposively selected giving a total of 12 town communities for the study. Ten (10) rice farmers were randomly selected from each of the town communities to give a total of 120 rice farmers for the study. The choice of random sampling was to give every farmer the chance of being selected. Data were collected by use of interview schedule. To determine the activities of rice farmers on the use of inorganic fertilizer, respondents were asked to indicate type of fertilizer they apply, time of application or rate of application, method of application, frequency of application, quantity of fertilizer used/applied annually per hectare of rice among others. The frequencies and percentages of responses were obtained. To ascertain factors that influence fertilizer use among rice farmers in the area, a multiple regression equation was used as stated below:

$$
Y=\beta_{0}+\beta_{1} X_{1}+\beta_{2} X_{2}+\ldots \ldots \ldots \ldots \ldots \ldots \ldots \ldots \ldots+\beta_{n} X_{n}+4
$$

Where:

$Y=$ Quantity of fertilizer used per growing season

$\mathrm{X}_{1}=\operatorname{sex}($ male $=1$ or female $=0)$

$X_{2}=$ Age of the farmers (years)

$X_{3}=$ Marital status (married $=1$, not married $=0$ )

$\mathrm{X}_{4}=$ Number of years spent in acquiring formal education.

$X_{5}=$ Years of experience in rice production

$\mathrm{X}_{6}=$ Household size

$\mathrm{X}_{7}=$ Total size of farm cultivated (hectare)

$\mathrm{X}_{8}=$ Total size of farm used for rice cultivation (hectare)

$\mathrm{X}_{9}=$ Membership of social organization (member $=1$, otherwise $=0$ )

$X_{10}=$ Total annual income earned from rice production

$\mathrm{X}_{11}=$ Quantity of rice produced in last growing season $(\mathrm{kg})$

$X_{12}=$ Number of time of inorganic fertilizer application per growing season

$X_{13}=$ Number of extension agent visit

$X_{14}=$ Amount spent in buying inorganic fertilizer per rice growing season

$\mathrm{B}_{1}=$ parameters to be estimated

$u=$ Error term

Data collected were analyzed using descriptive statistics (frequency, percentage and mean) and regression analysis. 
Creative Commons User License: CC BY-NC-ND

Abstracted by: EBSCOhost, Electronic Journals Service (EJS),

Google Scholar, Journal Seek, Scientific Commons,

Food and Agricultural Organization (FAO), CABI and Scopus

http://eoi.citefactor.org/10.11226/v26i1
Journal of Agricultural Extension

Vol. 26 (1) January, 2022

ISSN(e): 24086851; ISSN(Print); 1119944X

http://journal.aesonnigeria.org

http://www.ajol.info/index.php/jae

Email: editorinchief@aesonnigeria.org

\section{Results and discussion}

\section{Activities on the Use of Inorganic Fertilizer for Rice Production}

Table 1 shows that all respondents (100.0\%) used the broadcast method for applying inorganic fertilizer on their rice farms. This may be explained by the fact that broadcasting is the easiest and cheapest way to apply fertilizers. Okeke \& Oluka (2017), in a study in South East Nigeria, found that the fertilizer application method used by rice farmers in Ebonyi State is mainly a manual broadcast method. The table further reveals that a greater proportion (55.8\%) of the respondents applied inorganic fertilizer once on their rice farms, usually 2-3 weeks after planting. The practice of applying fertilizers at least twice during the growing season (split application), either using basal at planting or topdressed during vegetative growth increases grain yields (Liu et al., 2019). One of the reasons for this one-time application may be due to farmer's financial inability to procure the required quantity.

Table 1 also shows that $54.2 \%$ of the respondents applied Urea on rice farm; $45.0 \%$ applied NPK 27:13:13; 40\% applied NPK 20:10:10; 34.2\% applied NPK 15:15:15 while $1.7 \%$ of them applied Ebonyi fertilizer on their rice farm. This was done manually (92.5\%), implying that the respondents applied more of urea than other types of fertilizers probably because rice needs mainly nitrogen fertilizer. This result is consistent with that of Heffer and Prud'homme (2016) that urea is the most widespread used nitrogen fertilizer for rice cultivation. However, Iwuchukwu et al (2017), found that the majority (60\%) of rice farmers used 20:10:10 NPK to enrich their rice crop. Table 1 further reveales that greater proportion (49.2\%) of the respondents applied between $50-99 \mathrm{~kg}$ of inorganic fertilizer per hectare on rice farm. The mean quantity of inorganic fertilizer used per hectare of rice farm by the respondents was $85.63 \mathrm{~kg}$. This may mean that the respondents acquired and used such a quantity of fertilizer because of insufficient income or the exorbitant price of fertilizer. This is against the recommendation by the Federal Government of Nigeria (FGN) that the ideal fertilizer application rate for rice is $270 \mathrm{~kg} \mathrm{NPK}$ and $100 \mathrm{~kg}$ urea per hectare (International Fertilizer Development Center \& African Fertilizer and Agribusiness Partnership, 2018). It implies that farmers were using insufficient and under recommended quantity of fertilizer for rice production and this may have negative effect on output, yield and income. 
Creative Commons User License: CC BY-NC-ND

Abstracted by: EBSCOhost, Electronic Journals Service (EJS),

Google Scholar, Journal Seek, Scientific Commons,

Food and Agricultural Organization (FAO), CABI and Scopus

http://eoi.citefactor.org/10.11226/v26i1
Journal of Agricultural Extension

Vol. 26 (1) January, 2022

ISSN(e): 24086851; ISSN(Print); 1119944X

http://journal.aesonnigeria.org

http://www.ajol.info/index.php/jae

Email: editorinchief@aesonnigeria.org

Table 1: Activities in the use of inorganic fertilizer for rice production

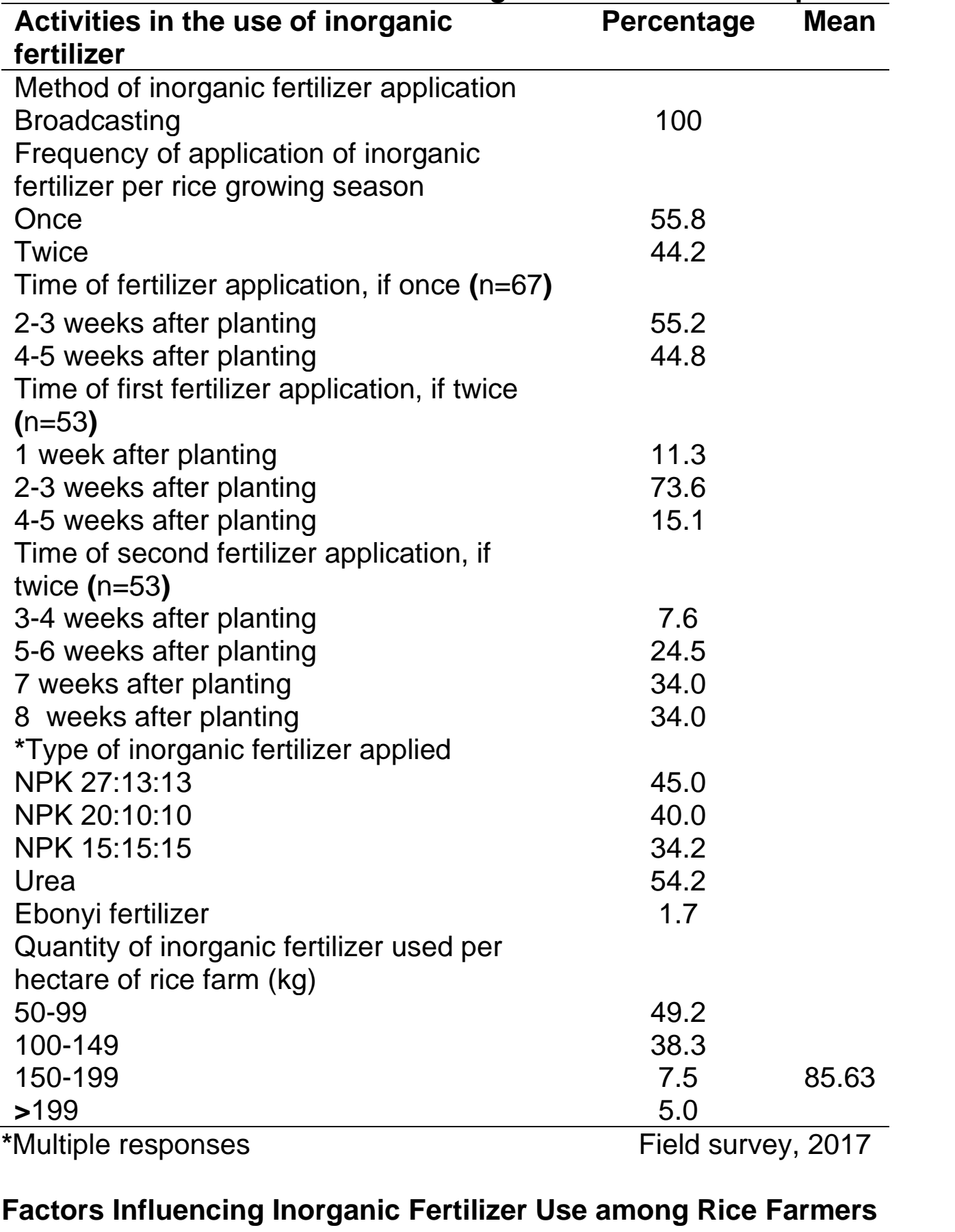


Creative Commons User License: CC BY-NC-ND

Abstracted by: EBSCOhost, Electronic Journals Service (EJS),

Google Scholar, Journal Seek, Scientific Commons,

Food and Agricultural Organization (FAO), CABI and Scopus

http://eoi.citefactor.org/10.11226/v26i1
Journal of Agricultural Extension

Vol. 26 (1) January, 2022

ISSN(e): 24086851; ISSN(Print); 1119944X

http://journal.aesonnigeria.org

http://www.ajol.info/index.php/jae

Email: editorinchief@aesonnigeria.org

Table 3 shows that there was a significant relationship between some socio-economic factors and inorganic fertilizer use $(F=16.008)$ accounting for $68.1 \%$ of the variance. Specifically, some of the socio-economic factors that had significant relationships with the quantity of fertilizer applied annually were: number of years spent in school ( $\mathrm{t}=1.991)$, years of experience in rice production ( $\mathrm{t}=2.197)$, total size of farm used for rice cultivation $(\mathrm{t}=3.441)$, total annual income from rice production ( $\mathrm{t}=3.286)$, number of extension visit $(\mathrm{t}=2.208)$. The positive significant relationship between the number of years spent in school and the quantity of inorganic fertilizer applied on rice farm indicates that formal education increases fertilizer use on rice farm. It may imply that people who are educated have better knowledge on the required quantity of fertilizer to apply on rice farm. This finding corroborates that of Aryal, Sapkota, Krupnik, Rahut, Jat and Stirling (2021) that education is one of the main socio-economic factors that can influence the quantity or amount of inorganic fertilizer use.

The positive relationship of years of experience in rice production and quantity of fertilizer applied also indicates that years of experience in rice production increases fertilizer use. This may mean that the higher the experience level, the greater a farmer uses inorganic fertilizer. The experience level may expose the respondents to the correct quantity to be applied and may serve as motivation to apply it on the rice farm. An experienced farmer is better informed about the importance of inorganic fertilizers and even when credit facilities are not available, he is more likely to have the advantage of fertilizer use. Also, the positive relationship between the size of the farm used for rice production and the quantity of fertilizer applied indicates that owning a large rice farm is may likely influence the quantity of fertilizer use. Therefore, the larger the size of the farm, the greater the quantity of fertilizer use and vice versa. This finding is not consistent with the study by $\mathrm{Hu}$, Zhang and Zhou (2019) which indicates that farmers with large farm size do not use more fertilizer for production than their counterparts.

The relationship between respondents' annual income and fertilizer application indicates that increase in annual income may also increase the quantity of inorganic fertilizer applied by rice farmers. This implies that low-income earners may use a small quantity of fertilizer on their rice farms. This is in congruence with Iticha, Jaleta and Mitiku, (2021) that income positively influenced intensity of fertilizer use in cereal crop production. Furthermore, the positive relationship of extension visit with the quantity of inorganic fertilizer applied on rice farm indicates that educating rice farmers on fertilizer use through extension services will invariably increase the quantity of inorganic fertilizer applied on the rice farm. Iticha et al. (2021) found that the frequency of extension contact positively influenced the intensity of fertilizer use among smallholder farmers. Surprisingly, there was no significant relationship between quantity of rice produced $(t=1.243)$ and fertilizer use. This may be caused by underuse of inorganic fertilizer as the average quantity applied is far below the recommended quantity per hectare. It may be due to lack of knowledge on appropriate type of inorganic fertilizer, inappropriate application method, 
Creative Commons User License: CC BY-NC-ND

Abstracted by: EBSCOhost, Electronic Journals Service (EJS),

Google Scholar, Journal Seek, Scientific Commons,

Food and Agricultural Organization (FAO), CABI and Scopus

http://eoi.citefactor.org/10.11226/v26i1
Journal of Agricultural Extension

Vol. 26 (1) January, 2022

ISSN(e): 24086851; ISSN(Print); 1119944X

http://journal.aesonnigeria.org

http://www.ajol.info/index.php/jae

Email: editorinchief@aesonnigeria.org

abuse or other malpractices in the use of the product. This may raise doubt on the fact that inorganic fertilizer remains an indispensible input for increasing food production in the world. The finding is at variant with Sainju, Ghimire and Pradhan (2019) who opined that application of $\mathrm{N}$ fertilizers has increased crop yields and resulted in achievement of self-sufficiency in food production in many developing countries

Table 3: Determinants of fertilizer use among rice farmers

\begin{tabular}{|c|c|c|c|c|}
\hline \multirow[t]{2}{*}{ Variables } & \multicolumn{2}{|c|}{$\begin{array}{l}\text { Unstandardized } \\
\text { Coefficients }\end{array}$} & \multirow{2}{*}{$\begin{array}{c}\begin{array}{c}\text { Standardized } \\
\text { Coefficients }\end{array} \\
\text { Beta }\end{array}$} & \multirow[t]{2}{*}{$\mathrm{T}$} \\
\hline & Beta & $\begin{array}{l}\text { Std. } \\
\text { Error }\end{array}$ & & \\
\hline (Constant) & $\begin{array}{c}- \\
226.214\end{array}$ & $\begin{array}{c}111.41 \\
3\end{array}$ & & $-2.030^{\star}$ \\
\hline Sex & 56.951 & 46.288 & 0.087 & 1.230 \\
\hline Age & -2.170 & 2.383 & -0.096 & -0.911 \\
\hline Marital status & 1.497 & 48.654 & 0.002 & 0.031 \\
\hline Number of years spent in school & 7.083 & 3.557 & 0.131 & $1.991^{*}$ \\
\hline $\begin{array}{l}\text { Years of experience in rice } \\
\text { production }\end{array}$ & 5.957 & 2.712 & 0.248 & 2.197 \\
\hline Household size & -3.473 & 3.001 & -0.085 & -1.157 \\
\hline Total size of farm cultivated (ha) & -11.740 & 8.257 & -0.129 & -1.422 \\
\hline $\begin{array}{l}\text { Total size of farm used for rice } \\
\text { cultivation (ha) }\end{array}$ & 66.726 & 19.393 & 0.364 & $3.441^{*}$ \\
\hline Membership of social organization & 18.575 & 34.781 & 0.034 & 0.534 \\
\hline $\begin{array}{l}\text { Total annual income earned from rice } \\
\text { production }\end{array}$ & 0.000 & 0.000 & 0.444 & $3.286^{*}$ \\
\hline $\begin{array}{l}\text { Quantity of rice produced in last } \\
\text { growing season }(\mathrm{kg})\end{array}$ & 0.001 & 0.001 & 0.159 & 1.243 \\
\hline $\begin{array}{l}\text { Number of time of inorganic fertilizer } \\
\text { application per growing season }\end{array}$ & 40.938 & 31.158 & 0.077 & 1.314 \\
\hline Number of extension agent visit & 81.608 & 36.967 & 0.139 & 2.208* \\
\hline $\begin{array}{l}\text { Amount spent in buying inorganic } \\
\text { fertilizer per rice growing season }\end{array}$ & 0.000 & 0.001 & -0.060 & -0.625 \\
\hline
\end{tabular}

$\mathrm{P} \leq 0.05$

Field survey, 2017

\section{Conclusion and Recommendation}

Rice farmers in Ebonyi state applied inorganic fertilizer twice on their rice farm using broadcast method. However, they did not use recommended quantity of inorganic fertilizer per hectare on rice farm. Rice farmers' inorganic fertilizer use were influenced by number of years spent in school, years of experience in rice production, total size of farm used for rice, total annual income earned from rice production and number of extension agent visit. Government through the ministry of agriculture should organize 
Creative Commons User License: CC BY-NC-ND

Abstracted by: EBSCOhost, Electronic Journals Service (EJS),

Google Scholar, Journal Seek, Scientific Commons,

Food and Agricultural Organization (FAO), CABI and Scopus

http://eoi.citefactor.org/10.11226/v26i1
Journal of Agricultural Extension

Vol. 26 (1) January, 2022

ISSN(e): 24086851; ISSN(Print); 1119944X

http://journal.aesonnigeria.org

http://www.ajol.info/index.php/jae

Email: editorinchief@aesonnigeria.org

workshops and train farmers on inorganic fertilizer use so as to enhance adequate use. Also, government and other relevant stakeholders in agriculture should ensure that inorganic fertilizers are available, accessible and affordable to farmers at all time so that they could maximally utilize it in rice production.

\section{References}

Aryal, J.P., Sapkota, T.B., Krupnik, T.J., Rahut, D.B., Jat, M.L., Stirling, c.m (2021). Factors affecting farmers' use of organic and inorganic fertilizers in South Asia. Environ Sci. Pollut. Res, 28, 51480-51496. https://doi.org/10.1007/s11356-021-13975-7

Bhandari, H. (2019). Global Rice Production, Consumption and Trade: Trends and Future Directions. Proceedings of the Korea society of crop science conference, 5-5.

Chaudhari, P.R., Tamrakar, N., Laxmi, S., Ambika, T., \& Deepark, S. (2018). Rice nutritional and medicinal properties: A review article. Journal of Pharmacognosy and Phytochemistry, 7(2), 150-156

Heffer, P., \& Prud'homme, M. (2016). Global nitrogen fertilizer demand and supply: Trend, current level and outlook. Proceedings of the International Nitrogen Initiative Conference on 4 - 8 December 2016, Melbourne, Australia. www.ini2016.com

Hu, L., Zhang, X \& Zhou, Y. (2019). Farm size and fertilizer sustainable use: An empirical study in Jiangsu, China. Journal of Integrative Agriculture, 18(12), 2898-2909

International Fertilizer Development Center (IFDC) \& African Fertilizer and Agribusiness Partnership (AFAP) (2018). Assessment of fertilizer distribution systems and opportunities for developing fertilizer blends Nigeria. Retrieved from: https://agra.org/wpcontent/uploads/2020/08/Nigeria-report_Assessment-of-Fertilizer-Distribution-Systemsand-Opportunities-for-Developing-Fertilizer-Blends.pdf

Iticha, M.D., Jaleta, M., \& Mitiku, F. (2021). Determinants and profitability of inorganic fertilizer use in smallholder maize production in Ethiopia. Cogent Food \& Agriculture, 7(1), 1911046 DOI: 10.1080/23311932.2021.1911046

Iwuchukwu, J.C., Ayogu, C.J., \& Udegbunam, I.C. (2017). Activities of farmers in rice production in Awka North Local Governmenment Area, Anambra State, Nigeria. Journal of Experimental Agriculture International, 17(2), 1-10.

Jaja, E.T., \& Barber, L.I. (2017).Organic and Inorganic Fertilizers in Food Production System in Nigeria. Journal of Biology, Agriculture and Healthcare, 7 (18), 51-55

Jat, R.D., Kakraliya, S.K., Choudhary, K.K., Kapoor, P., Kakraliya, S.S, \& Ram, H. (2020). Advances in rice production technologies. In: A.S. Yadav, N. Kumar, S. Arora, D.S. Srivastava, \& H. Pant (ed.). Advances in crop production and climate change. New India Publishing

Liu, Z., Gao, F., Liu, Y., Yang, J., Zhen, X., Li, X., Li, Y., Zhao, J., Li, J., Qian, B., \& Yang, D. (2019). Timing and splitting of nitrogen fertilizer supply to increase crop yield and efficiency 
Creative Commons User License: CC BY-NC-ND

Abstracted by: EBSCOhost, Electronic Journals Service (EJS),

Google Scholar, Journal Seek, Scientific Commons,

Food and Agricultural Organization (FAO), CABI and Scopus

http://eoi.citefactor.org/10.11226/v26i1
Journal of Agricultural Extension

Vol. 26 (1) January, 2022

ISSN(e): 24086851; ISSN(Print); 1119944X

http://journal.aesonnigeria.org

http://www.ajol.info/index.php/jae

Email: editorinchief@aesonnigeria.org

of nitrogen utilization in a wheat-peanut relay intercropping system in China. The Crop Journal, 7 (1), 101-112

Mohammed, U. A., Ibrahim, S.,Hayatu, M.,\& Mohammed, F. A. (2019). Rice (Oryza Sativa L.) Production in Nigeria: Challenges and Prospects. Dutse Journal of Pure and Applied Sciences (DUJOPAS), 5 (2b), 67-75.

National Population Commission (NPC) (2006). Population figure, Federal Republic of Nigeria, Abuja. Retrieved from: http://www.npc.gov.

Okeke, C. G., \& Oluka, S. I. (2017). A survey of rice production and processing in South East Nigeria. Nigerian Journal of Technology (NIJOTECH), 36 (1), 227 - 234.

Onya, S.C., Okezie, C.A. \& Ejiba, I.V. (2019). Double hurdle modelling approach to local rice consumption in Ikwuano Local Government Area of Abia State, Nigeria. Agro-Science, 18 (2), 20-25. DOI: https://dx.doi.org/10.4314/as.v18i2.4.

Raimi, A., Adeleke R.,\& Ashira Roopnarain, A. (2017). Soil fertility challenges and Bio fertilizer as a viable alternative for increasing smallholder farmer crop productivity in sub-Saharan Africa. Cogent Food \& Agriculture, 3(1), 1400933. DOI: $10.1080 / 23311932.2017 .1400933$

Sainju, U.M., Ghimire, R \& Pradhan, G.P. (2019). Nitrogen Fertilization I: Impact on crop, soil, and environment. IntechOpen. DOI: http://dx.doi.org/10.5772/intechopen.86028

Saleh, A.S.M., Wang, P., Wang, N., Yang, L., \& Xiao, Z. (2019). Rice brown versus white rice: Nutritional quality, potential health benefits, development of food products, and preservation technologies. Comprehensive Reviews in Food Science and Food Safety, 18, 1070-1096. DOI: $10.1111 / 1541-4337.12449$

Udemezue, J.C. (2018). Analysis of rice production and consumption trends in Nigeria. Journal of Plant Sciences and Crop Protection 1(3), 305-310.

Yang, Q.Q., Suen, P.K., Zhang, C.Q., Mak, W.S., Gu, M.H., Liu, Q.Q., \& Sun, S.S.M. (2017). Improved growth performance, food efficiency, and lysine availability in growing rats fed with lysine-biofortified rice. Scientific Reports, 7,1389. DOI:10.1038/s41598-017-01555-0 